\title{
histórica \\ Balaiada: construção da memória
}

Maria de Lourdes Monaco JANOTTI ${ }^{1}$

\begin{abstract}
RESUMO: Durante o século XIX, historiadores procuraram explicar o nascimento do Estado nacional brasileiro, atribuindo às instituições do novo país independente um caráter constitucional, renovador e civilizado. Nessa medida, os movimentos contestatórios, entre eles a Balaiada, foram julgados como anomalias, manifestações da barbárie contra a civilização, representada pela ordem monárquica. Entretanto, fontes memorialísticas veicularam versões diferentes da revolta balaia, ricas em detalhes e nuances, permitindo apreender variações comportamentais de segmentos sociais emergentes na crise final do período colonial. Entrando pelo século XX historiadores compreenderam que a Balaiada representou a ascensão de brasileiros ao poder provincial e nacional, a consolidação do poder do coronelismo e o pacto de dominação entre os partidos da elite maranhense, acentuando mais ainda a marginalização social dos destituídos, principalmente dos negros.
\end{abstract}

PALAVRAS-CHAVE: Balaiada; partidos maranhenses; revoltas da Regência.

Concebendo a história como vida, a memória oral ou escrita como representação testemunhal do vivido e a historiografia como narrativa interpretativa baseada em métodos e técnicas, percebe-se a existência de uma relação dialética entre esses conceitos. História, memória e historiografia interagem entre si de forma constante e dinâmica, não significando, entretanto, que em essência sejam da mesma natureza. 


\section{FONTES MEMORIALÍSTICAS}

A produção historiográfica e memorialística sobre a Balaiada reproduz, em grande parte, as linhas gerais das matrizes explicativas mais abrangentes da historiografia brasileira, decisivamente vinculadas à compreensão da questão nacional .

Durante o século XIX, intelectuais procuraram explicar o nascimento do Estado nacional brasileiro, empenhando-se em atribuir às instituições do novo país independente um caráter constitucional, renovador e civilizado. Tudo que fugisse a esse próspero modelo era rechaçado, considerado um desvio. Nessa medida, os movimentos contestatórios, entre eles a Balaiada, foram julgados como anomalias, manifestações da barbárie contra a civilização, representada pela ordem monárquica. Entretanto, essa não foi uma posição unânime. Fontes memorialísticas, como os escritos de João Francisco Lisboa e depoimentos de época, colhidos por Dunshee de Abranches, veicularam versões da revolta balaia menos esquemáticas e homogêneas e mais ricas em detalhes e nuances.

João Francisco Lisboa foi historiador, político e jornalista crítico dos costumes políticos. Quando jovem foi "exaltado", tendo participado da setembrada por ocasião da abdicação de D. Pedro, mas desaparecendo o perigo da restauração alinhou-se com os liberais da província que combatiam a política centralizadora da regência de Araújo Lima.

A Crônica M aranhense era a principal tribuna de onde se dirigiam ataques e críticas ao governo, demonstrando inegável simpatia ao grupo Bem-te-vi, sendo por essa razão acusado de fomentar o clima revolucionário na província. Publicava correspondência sobre o desenvolvimento das ações rebeldes, reclamações sobre o confisco de rebanhos, depredações, saques e violências de toda espécie cometidos principalmente pelos cabanos. Fica bem claro através dessas notícias as ligações do Partido Liberal com os grupos armados do Pará, Maranhão, Piauí e Alagoas e o cotidiano da população urbana e rural sob as exigências das faç̧ões em luta. 
Como jornalista, expressou os primeiros temores de um país recém-emancipado; denunciou os excessos da interferência das questões políticas na esfera administrativa; soube perceber nas origens da Balaiada a opressão sob a qual vivia a população marginalizada maranhense. Entretanto, não foi extremado a ponto de tornar-se republicano ou revolucionário, mas denunciava vigorosamente a lei dos prefeitos, o recrutamento forçado e a improbidade das autoridades governamentais.

A insuficiência teórica de João Francisco Lisboa, presente nos escritos políticos do Jornal de Timon, representa as dificuldades encontradas pelos intelectuais de sua geração em compreender a complexa realidade do País, que continha em si contradições insuperáveis geradas pela permanência da antiga estrutura econômico-social, principalmente a da escravidão, ao lado de formas ambiciosamente liberais de governo.

A pesar de ter constatado e denunciado os abusos de poder, os perigos do autoritarismo, a falta de ideologia dos partidos do Império, a negação absoluta do direito revolucionário, mudanças político-administrativas inadequadas, a outorga de poder a funcionários subalternos e incompetentes, não chegou a contestar o regime.

Juntamente com o Partido Liberal, abandonou as forças populares balaias quando estas se aproximaram perigosamente de São Luís e o governo enviou Luís Alves de Lima para comandar a repressão. Não demonstrou confiança no apoio popular, residindo nesse fato a impossibilidade de desenvolver, até as últimas conseqüências, a doutrina liberal que esposava, antevendo apenas no fortalecimento do poder moderador do rei possibilidades de moralizar a vida pública e promover 0 progresso material. Por temer que as mudanças radicais levassem o Brasil a uma situação idêntica à das republicas da América Latina, preferiu a manutenção da situação vigente. ${ }^{2}$

Enquanto João Lisboa preocupou-se mais com a memória política, no interessante livro de João Dunshee de Abranches Moura, "O captiveiro. M emórias", ${ }^{3}$ dominado por figuras femininas e pela denúncia da escravidão, encontram-se relatos e documentos significativos sobre a sociedade maranhense do século XIX. Baseou-se em apontamentos de sua adolescência, 
registrados por volta de 1880 , quando consultou pela primeira vez a correspondência de sua avó materna M arta Alonso Alvarez de Castro Abranches (espanhola, 1800-1855) e entrevistou com impressionante acuidade - numa antevisão dos procedimentos da história oral -, Emília Pinto Magalhães Branco natural de Lisboa (1818-1888), mãe dos escritores Aluízio, Artur e Américo de Azevedo.

0 autor não esconde a grande admiração nutrida por sua avó, celebrada educadora de São Luís. Em 1844, fundou o colégio N ossa Senhora da Glória, popularmente denominado colégio dos Abranches, primeira escola feminina de São Luís. A correspondência de M arta com seu marido Garcia de Abranches, do Partido Restaurador, capitalista e fazendeiro estabelecido em São Luís, divide-se em duas séries. A primeira, constituída de cartas datadas de 1831, informa-0 das lutas políticas dos restauradores e patriotas por ocasião de sua ida para os Açores, com o objetivo de juntar-se à expedição de D.Pedro I - que pretendia repor D. M aria II no trono. A segunda série, na qual ela relata os acontecimentos da época da Balaiada, foi escrita em 1838 durante a permanência de Garcia de Abranches em Portugal, empenhado em negócios financeiros com a Coroa.

As entrevistas com Emília, portuguesa, filha de rico negociante, mulher inteligente, culta, possuidora de invejável memória, e por esta razão foi considerada "crônica viva da cidade", abrangem o período de 1818 a 1880. Não faltam observações valiosas do entrevistador sobre as emoções da narradora e o ambiente que a cercava, muito semelhantes às registradas pelos pesquisadores atuais em seus cadernos de campo. Emília conviveu com M arta desde sua vinda de Portugal, havia entre ambas profunda afinidade de pensamento e mútua admiração, o que imprime traços de complementaridade ao seu depoimento e à correspondência da avó de Dunshee de Abranches.

As questões mais comentadas pelas duas mulheres foram os acontecimentos da Balaiada e aquelas próprias da sociedade escravista maranhense. 
Ao terminar a luta civil, a inquietação aparentemente sufocada, M arta emitiu seu juízo em carta ao marido:

M isturar sangue é misturar destinos [...] Os mestiços julgam-se os senhores da terra; cognominam-se de nativos. Os brancos para eles, mesmo os que vieram à luz aqui, são adotivos como os estrangeiros que declararam aceitar a nacionalidade brasileira. São estes mestiços que formam o grosso do partido bem-te-vi [...] Os bem-te-vis eram os farroupilhas maranhenses [...] mas não visavam a queda da monarquia, queriam apenas que se cumprissem as reformas liberais decorrentes do gol pe político do 7 de Abril. ${ }^{4}$

$\mathrm{N}$ a última carta da série, a nobre espanhola discorre sobre a pacificação e a anistia:

O que mais influiu, porém, para a pacificação, foi sem dúvida a declaração da maioridade do jovem monarca. Lima prometeu logo perdoar os que depusessem incondicionalmente as armas. Mas o fez só em parte [...] quanto ao negro Cosme, como bem previ e te anunciei, foi metido a ferros na cadeia, aqui, na capital. Garantem os cabanos que seguirá em breve para o Itapicuru onde será solenemente enforcado em presença de numerosos escravos da região para que o seu suplício sirva de exemplo aos que ainda sonham fugir das fazendas para os quilombos. Bela anistia, meu caro Censor! $!^{5} E$ dizerem por aí que ela foi a morte do cangaço! Do cangaço? Não: da Balaiada. $O$ cangaço é a alma bravia dos sertões. E as almas bravias não se dominam pela força; domam-se só pelos influxos do ensino e da fé! ${ }^{6}$

Essa interpretação de M arta é coerente com todo o teor de sua correspondência. Sempre foi mulher muito enfronhada na política, tendo convivido em vários círculos partidários na Europa e no Brasil. Teve experiência direta com a resistência espanhola, emigrados europeus e movimentos e guerras restauradoras. No Maranhão, embora convivesse com os próceres do Partido Caramuru, tinha tolerância em relação aos 
demais, procurava compreender suas razões. Sua visão crítica era bem diferente da dos cabanos em geral, na medida em que punha sua análise acima das questiúnculas da terra. Via a H istória como um processo no qual a injustiça e o cerceamento das liberdades promoviam reações contrárias, cada vez mais violentas porque o ser humano era instintivamente livre. Previa o aumento dos contingentes marginalizados que formavam o cangaço em razão da anistia sel etiva que foi concedida e das punições e assassinatos de seu quadro de lideranças. Seu julgamento não só difere do da maioria, liberal ou conservadora, mas se afina com princípios amplos do liberalismo. Talvez sua alta estirpe Ihe conferisse a complacência que a nobreza de sangue podia ter em relação a todos os plebeus que a cercavam.

As rememorações de Emília Branco sobre as desgraças cotidianas de sua época são precisas e minuciosas. Ela considerava a Balaiada um divisor de águas: Às grandes catástrofes civis seguiam-se quase sempre períodos de funda reparação espiritual. Com essa expressão introduz em sua rememoração um excelente panorama do período de florescimento das letras, ciências e artes do Maranhão, o qual acompanhou e dele participou. Entretanto, não deixou de mencionar graves preconceitos e "baixos costumes" que subsistiam na vida social, os quais considerava herança nefasta dos tempos coloniais, provindos da crueldade do regime da escravidão e da permissividade sexual dos senhores de escravos.

Em sua visão, a Balaiada agravara ainda mais a dissolução dos costumes:

Ao rebentar o movimento, o pânico se apoderara das populações rurais [...] Os escravos ganharam logo as matas, repudiando 0 cativei ro. Os fazendeiros e seus feitores, receando as vinditas dos oprimidos, correram a homiziar-se na capital. Muitos abandonaram bruscamente esposas e filhas na persuasão de que, como mulheres, estavam menos expostas aos perigos. Algumas dessas, sem a mínima instrução, embrutecidas pelas práticas licenciosas das senzalas, entregaram-se levianamente ou por terror à libidinagem dos insurretos ou se ligaram aos próprios escravos, seus prediletos [...] Houve numerosos infanticídios 
para se ocultarem estupros e adultérios [...]. Os homens que sempre haviam imposto concubinas negras às suas famílias vingaram-se, com requintes perversos, daquilo que consideravam atentado à sua honra.

O discurso de Emília é francamente de repúdio à escravidão e em defesa dos direitos das mulheres, visto ela própria ter sido vítima de pai e marido intransigentes, durante seu primeiro casamento. Parte do pressuposto que a escravidão corrompera a sociedade. Esta se dividia entre os formados sob o influxo das senzalas, tornando-se supersticiosos, cruéis e imorais, e os que repudiavam tal sistema. Embora sua visão fosse comum entre os antiescravocratas, não atribuía à cultura africana nenhum atributo corruptor, como muitos o faziam, e sim à degradação dos senhores brancos:

0 regime da escravidão embotou fundamente os corações. Os negros africanos viviam colocados abaixo dos animais domésticos nas casas onde serviam. Mal alimentados, curtidos de sevícias, não Ihes era permitido terem descanso, nem sono, nem moléstias. Dia e noite labutavam rudemente, quer nos trabalhos do senhor, quer alugados para as obras públicas. 0 preto de canga em São Luís tinha aspecto monstruoso: forçado a carregar aos ombros toneladas e a servir de máquina de quebrar blocos enormes de cantaria, além de roído sempre pelas verminoses, tornava-se cambaio e apresentava o corpo coberto de hérnias.'

As fontes memorialísticas permitiram apreender variações comportamentais de segmentos sociais emergentes na crise final do sistema colonial, representando modos de pensar e agir de uma sociedade em efervescência, onde o rural e o urbano, nitidamente, começavam a se diferenciar.

As rememorações, vistas como versões subjetivas do momento vivido, adquiriram expressividade no conjunto de outras fontes, representando modos de pensar e agir de uma sociedade em efervescência, onde o rural e o urbano nitidamente começavam a se diferenciar.

Não era mais possível identificar uma classe senhorial homogênea. Distanciavam-se os pequenos proprietários de 
terras do interior dos grandes proprietários que viviam nos centros urbanos, e não só isso; entre estes últimos, à adoção de costumes e padrões burgueses tornaram-se elementos que os distinguiam e dividiam.

Sem exageros é possível afirmar ter a tragédia da Balaiada, representado a ascensão de brasileiros aos poderes provincial e nacional, acentuando mais ainda a marginalização social dos destituídos, o poder coronelístico e o pacto de dominação entre os partidos da elite maranhense.

\section{INTÉRPRETES DA BALAIADA}

Na primeira metade do século $X X$, em pleno clima de contestações provenientes do mundo do trabalho, do movimento tenentista, da fundação do Partido Comunista e da Revolução de 30, os historiadores preocuparam-se em compreender as razões dos principais problemas do País. Dessa forma, dedicaram-se ao estudo do poder oligárquico, do coronelismo e das estruturas econômicas, revendo muitos julgamentos anteriores sobre os movimentos de rebeldia popular.

Como as demais revoltas da regência, a Balaiada foi reinterpretada por cronistas e historiadores maranhenses principalmente no que tange ao caráter dos chefes dos grupos armados.

Apesar de haver mais de vinte anos de intervalo entre a publicação dos livros de Carlota Carvalho (O Sertão, em 1924) ${ }^{9}$ e 0 de Astolfo Serra (A Balaiada, 1948), ${ }^{10}$ ambos pretenderam reabilitar os chefes balaios, anteriormente acoimados de vândalos, celerados, selvagens, sem consciência política, etc. Trabal hos de cunho local pouca repercussão tiveram no conjunto da historiografia revisionista, por carecerem de fundamentação científica.

Elizabeth Sousa Abrantes escreveu, em 1996, sobre esses autores, ${ }^{11}$ atestando o interesse que ainda despertavam:

Carlota Carvalho foi a primeira a considerar os rebeldes como "corajosos, intrépidos, leais, dedicados, saídos das classes laboriosas e honestas - agricultores, vaqueiros, fazendeiros e 
trabalhadores rurais brasileiros muito nativistas." ${ }^{12}$ [...] Desse modo, a descrição que faz dos rebeldes contradiz aquela apresentada por D omingos de M agalhães e Ribeiro do Amaral.

Para Astolfo Serra, os milhares de "caboclos" e "negros quilombolas", que pegaram em armas no Maranhão no fim do Período Regencial, não devem ser considerados como meros bandidos, porque os seus "crimes, os desatinos cometidos, as violências e atrocidades foram conseqüências e não causa dessa guerra". "A Balaiada não foi uma aventura, nem política, nem de banditismo; foi antes um fenômeno de acentuadas características revolucionarias, quase comunista, e que se manifestou como movimento de massa com caráter de reabilitação social [...]. M ilhares de camponeses [que] se unem pelo mesmo espírito de rebeldia. ${ }^{13}$

Os escritos memorialísticos e as crônicas locais foram reinterpretados pela historiografia dos anos 70 e 80 do século $X X$, quando as tendências explicativas se multiplicaram e diversificaram com destaque para as explicações influenciadas pela sociologia e pelo marxismo. Estudos privilegiando abordagens econômico-sociais centraram-se nas questões político-sociais da América Latina, das ditaduras e da repressão favorecidas pelo imperialismo capitalista. Compreender as estruturas sociopolítico-econômicas tornou-se ordem do dia.

Proporcionadas pela pesquisa acadêmica minuciosa, foram acrescentadas à construção da memória da Balaiada novas dimensões, entre outras: a da luta de classes, da resistência escrava, do confronto entre camponeses, agregados e proprietários. Concomitantemente, vinculados à perspectiva da totalidade histórica, os historiadores construíram novas explicações sobre a formação do Estado brasileiro.

Em 1983, Maria Januária Vilela Santos interpretou o processo revolucionário balaio, aprofundando o estudo da participação escrava: ${ }^{14}$

A dinâmica do processo acabou desaguando na própria insurreição negra. 0 poder armado e revelado dos balaios, assim como a ameaça destes de entregar esse poder aos "homens de cor", foi o fator decisivo na reformulação do comportamento do Partido Liberal. 0 perigo atingia agora o próprio sistema 
escravista e as bases da sua sociedade. Os principais setores livres da sociedade maranhense - a elite agrária-urbana e a camada livre pobre - tiveram comportamentos diferenciados, em relação à rebeldia negra. Inicialmente, os lideres revelaram de forma indiscutível a não aceitação do escravo no movimento que iniciavam. É sabido que, ao conclamar os "cidadãos brasileiros e amigos da Pátria" em famoso manifesto (de 14 de dezembro de 1838), Raimundo Gomes excluiu a grande massa escrava com um "Fora feitores e escravos!" Este foi um dos limites sociais impostos à vinculação efetiva entre negros e homens livres pobres. [...]. Mas, a ampliação da revolta e a sua própria dinâmica afetaram não só as lideranças rebeldes como 0 comportamento político da elite provincial. Algumas posições rebeldes radicalizaram-se: rejeição aos liberais como mentores teóricos da luta e maior vinculação com os negros numa luta de "homens de cor" contra os brancos.

As possibilidades de junção entre balaios e escravos são visíveis em dois momentos. Um foi quando, após a tomada de Caxias, segunda cidade da província, o movimento balaio radicalizou-se aprofundando as diferenças sociais entre seus próprios componentes [...]. O segundo momento foi quando as forças balaias se esfacelavam no segundo semestre de 1840, ocasião em que Raimundo Gomes tenta realmente sublevar o maior numero possível de escravos, num esforço de coordenar o movimento, agora basicamente negro. No entanto, as condições sociais escravistas responsáveis pela rejeição entre homens livres e escravos persistem até o final da luta, alimentadas que foram pela legalidade. A insurreição de escravos causou maior pânico que a própria Balaiada, uma vez que ameaçava as bases do sistema escravista. ${ }^{15}$

Em 1987, a autora deste artigo-conferência escreveu um livro sobre a Balaiada ${ }^{16}$ e ainda hoje concorda com as idéias nele expostas.

Em síntese, penso que o período regencial (1831-1840), sempre identificado como de "triste memória" pelo elevado número de levantes, insurreições e revoluções que nele ocorreram, talvez seja um dos mais importantes para o estudo da formação social brasileira. Historiadores atribuíram, apressadamente, à fraqueza própria das regências esse clima de 
insubordinação. No entanto, nem o trono é garantia de paz, nem as regências são necessariamente atribuladas.

Cristalizou-se uma memória negativa dessa época com vínculos ideológicos bem próximos aos dos discursos elaborados pelos "construtores do Império", isto é, os políticos vitoriosos conservadores do Segundo Reinado. A fim de reforçar a idéia de pacificação nacional, após a derrota da Praieira, e solidificar 0 terreno da ilusória conciliação partidária, proliferaram interpretações sobre as agruras passadas: tinha sido um período transitório, excepcional em nossa história, fruto da imaturidade da ex-Colônia, mas todos já haviam compreendido que apenas sob a bandeira do I mpério era possível solidificar os laços patrióticos.

Tão rica de impacto ideológico foi essa vertente explicativa, que chegou a influenciar posteriormente historiadores que valorizaram o significado dessas rebeliões. Reconheceram estes 0 sentido democrático subjacente em algumas delas, acentuando a idéia da existência de um ciclo revolucionário circunscrito à Regência.

Algumas objeções podem ser levantadas a respeito desses julgamentos. Movimentos de insubordinação ocorreram, com freqüência, em todos os períodos, desde a Colônia até a República: portanto, não são específicos da Regência. Uma leitura atenta dos testemunhos sobre a Cabanagem, a Sabinada, a Farroupilha e a Balaiada revela mais divergências do que semelhanças entre esses acontecimentos.

Se o Ato Adicional (medida descentralizadora do poder) e, mais tarde, a Lei de Interpretação do Ato Adicional (medida centralizadora) têm importância substantiva no desenvolvimento das rebeliões, e isso atestam variadas fontes, no entanto 0 impacto dessas medidas desencadeou reações revolucionárias diversas. Uns revoltaram-se pela aplicação estrita da lei e outros por julgá-la demasiadamente tímida; estes por sentirem-se prejudicados, aqueles por ainda não disporem de meios mais radicais para prejudicar os adversários. Portanto, a pluralidade de insatisfações é de tal monta, que se torna temerário apontar as duas leis do governo como denominadores comuns geradores de um ciclo de revoltas. 
Há, entretanto, vários componentes complicadores nesse quadro, dentre os quais sobressai, de forma preponderante, a formação das classes dominantes brasileiras. $\mathrm{Na}$ base das agitações estão as lutas travadas entre diferentes segmentos sociais que vinham se depurando nos conflitos coloniais pelo controle de vilas, capitanias e favores reais. Com a Independência, disputaram palmo a palmo o poder que se lhes apresentava de forma mais concreta.

Pesaram muito, nesse momento, os problemas econômicos de cada província, bem como a crescente influencia inglesa no País. Para fazer frente à nova situação não bastava aos grandes proprietários e comerciantes o exercício de limitada influência local: esforçaram-se também para ascender à administração do Império.

Havia um abismo entre os políticos do Rio de Janeiro e os das províncias. A Corte, pólo centralizador das decisões, com hábitos e atividades urbanas sedimentadas, era a metrópole do resto do Brasil agrário. Concordando com Raymundo Faoro sobre a natureza patrimonialista do Estado brasileiro, compreende-se que era a posse de cargos na administração pública, mesmo os de caráter honorífico, que garantia respeitabilidade, enriquecimento, e principalmente 0 reconhecimento da autoridade. Portanto, não bastava ser comerciante ou possuir terras e escravos, era preciso representar o governo e impor-se aos políticos da Corte que monopolizavam as fontes de poder.

Somaram-se aos problemas de organização do Estado nacional as divergências dos interesses provinciais, representativos de um dos momentos iniciais em que começa a engendrar-se 0 discurso das classes dominantes brasileiras. Sem dúvida foi necessário um longo percurso para que os papéis se definissem melhor e a ordem do Estado expressasse a constituição de uma sociedade de classes. Entretanto, as revoltas do período regencial - que envolveram na mesma luta escravos, índios, brancos pobres, jagunços e toda sorte de marginalizados ao lado de comerciantes, senhores de engenho e proprietários de grandes rebanhos - tiveram relevância inquestionável na 
definição dos limites dos espaços de dominantes e dominados. A Balaiada foi uma delas.

Generalizou-se a interpretação de que, uma vez organizado o centro decisório no Rio de Janeiro, este concentrou sua ação em pacificar as províncias rebeladas. Contudo, apesar das enormes distâncias, houve uma interação constante entre os sucessos da política central e os da política provincial. Concomitantemente, no dia-a-dia do desenrolar dos acontecimentos em diferentes espaços geográficos, foram construídos os pólos de poder que deram coesão à dominação de classe no País. Não só as rebeliões desenharam seu curso, impulsionadas pelas medidas que partiam do governo central, como também a adoção dessas medidas em muito dependeu do trajeto revolucionário.

A luta política que se travou no Rio de Janeiro, pela direção do governo central, foi intensa por todo o período regencial. Não chegou a haver conflito armado, expressando-se, todavia, a disposição belicosa em golpes e contragolpes políticos.

Não havia ainda clareza quanto à ideologia dos grupos políticos que se abrigavam sob a denominação de moderados ou liberais. Pareciam apenas excluídos do "congraçamento liberal" aqueles que esposavam o republicanismo. Conseqüentemente, seria no desenvolver da política cotidiana da Câmara e do governo dos regentes que se definiram os núcleos políticos hegemônicos, consubstanciados no aparecimento dos partidos Liberal e Conservador.

Com a renúncia de Feijó, os conservadores vitoriosos assumiam o poder no governo do substituto legal do regente, 0 ministro do Império Araújo Lima. O novo regente designou Bernardo Pereira de Vasconcelos para as pastas da Justiça e do Império. Este teria agora a oportunidade de experimentar na prática governativa suas receitas para "parar 0 carro revolucionário". Na liderança do Ministério, tomaria logo medidas centralizadoras, algumas anticonstitucionais, na expectativa da elaboração de uma lei "que interpretasse o Ato Adicional, corrigindo seus desvios". Detendo agora cargos na administração, passariam a reprimir violentamente os "exaltados", contrariando interesses de setores das elites locais. 
A emergência de um discurso das camadas sociais marginalizadas, de forte conteúdo social, permeava, de muito, as fórmulas de protesto do discurso liberal empregadas nos manifestos e proclamações revolucionárias. Nesse clima de avanço e recuos da construção do poder, surgiu a Balaiada em 1838.

Durante todo o período inicial da Balaiada, os bem-te-vis não cansaram de responsabilizar os cabanos pelo crescimento da revolta, pela ineficiência da administração, pela corrupção da guarda nacional, aproveitando-se da insegurança geral, vaticinar um grande derramamento de sangue na província. A cúpula do partido dos bem-te-vis pretendeu manipular os revoltosos, transformando-os em instrumentos de suas ambições através de hábil campanha jornalística, na qual divulgou vários manifestos dos chefes do movimento, veiculando as razões que os moviam, sem contudo hipotecar-Ihes solidariedade. Esqueciam, porém, que fazendeiros do sertão, pertencentes ao seu próprio partido, integravam as forças balaias. Estes seriam submetidos, no final do movimento, pelos proprietários que conseguiram ter acesso ao aparelho do Estado, concentrados na capital da província. Estavam-se constituindo, sem dúvida, as classes dominantes maranhenses, eliminando da hegemonia alguns de seus segmentos.

Com a tomada de Caxias, segunda cidade da província, em julho de 1839, significativas mudanças operaram-se tanto no comportamento político dos grupos dominantes, como no desenvolvimento da ação revolucionária. Em São Luís, o temor de uma marcha "rebelde" sobre a capital generalizou-se. Os habitantes da cidade começaram a se preparar para a resistência.

Até então, os liberais (bem-te-vis) haviam adotado várias posições em relação ao movimento. Os da capital procuraram através dele conseguir sucesso nas eleições que se aproximavam e novamente controlar o governo. No interior a situação era muito mais complexa. Alguns participaram francamente da revolução; outros, muito mais numerosos, colocaram-se na situação de vítimas constrangidas a colaborar, esperando, com essa justificativa, que os acontecimentos futuros os ben eficiassem. 
Os liberais visaram a uma saída para sua incômoda situação. Não deixando de hostilizar o partido cabano, acercaram-se do presidente - que passou a ser considerado uma figura apartidária - para fazer frente a esse momento crítico. Assim demonstravam toda a sua fraqueza ideológica e, claramente, revelavam a exploração que vinham fazendo da luta balaia, em proveito próprio.

A repressão violenta de Luís Alves de Lima, enviado pelo governo central, foi apoiada por todas as facções liberais e cabanas. Temiam os balaios entregarem-se às forças oficiais, pois, quando os primeiros grupos se renderam, ou aceitaram a proposta da anistia, foram obrigados a combater seus próprios correligionários. 0 final da Balaiada foi marcado pela traição, assassinatos, deserções, prisões e torturas, atestados nos relatórios firmados pelo presidente.

Nos últimos momentos D.Cosme ficou só. Não tinha motivos para entregar-se. Suas tropas lutavam sem nenhuma esperança, eram escravos, não queriam voltar ao jugo de seus senhores, pois tinham sido homens livres e temidos. Lutaram até a morte. D.Cosme foi enforcado em praça pública, oferecendo à população o espetáculo de uma punição exemplar. Acabava a Balaiada.

Os partidos maranhenses locais, que viveram durante anos em torno das questões levantadas pela revolta, desarticularam-se com o seu final: as antigas lideranças foram substituídas; do poderoso partido cabano pouco restava; o exaltado partido dos bem-te-vis desaparecia, amedrontado pela violência da repressão. Contudo, em lugar dos partidos beligerantes, estruturaram-se parlamentarmente liberais e conservadores, repartindo entre si não só os cargos administrativos e burocráticos do governo provincial, como também a composição da representação maranhense na Câmara e no Senado.

A população marginalizada, que havia lutado durante anos, enfrentaria enormes dificuldades para ser reabsorvida em atividades produtivas; venderia sua força de trabalho a preço vil, ou continuaria nômade a percorrer o sertão em busca de um meio de sobrevivência. Apresentava-se com maior dramaticidade a irresolução do problema social, ainda mais que os preços do 
açúcar e do algodão haviam mergulhado em longa crise de depreciação.

Muitos grupos se mantiveram armados e preferiram internar-se no sertão e vender proteção aos coronéis locais, formando bandos de cangaceiros. Outros, entretanto, continuaram a lutar em áreas conturbadas do $M$ ato Grosso e do Pará. Dessa maneira, com as lutas da regência havia-se formado um contingente de homens armados sempre prontos a arregimentar-se sob qualquer bandeira.

Com o desenrolar das lutas travadas em todo o I mpério, os segmentos sociais das classes dominantes começaram a se ajustar, reconhecendo-se uns aos outros e delimitando suas áreas de influência. Não deixava de ser paradoxal terem esses comerciantes e latifundiários conseguido assenhorear-se da máquina administrativa do Estado, no momento em que a atividade cafeicultora estava prestes a assumir a liderança das exportações brasileiras, já fazendo antever o novo pólo de hegemonia do poder.

Retomando o percurso historiográfico que vínhamos trilhando, deve-se notar um outro aspecto da historiografia dos anos 80 foi a utilização da história oral fazendo emergir um sujeito histórico novo: o homem anônimo. Temas reveladores da história e da memória dos excluídos - pobres, doentes, índios, trabalhadores rurais, mulheres, afro-brasileiros, presos e outros influenciaram releituras da Balaiada, como a realizada por $M$ atthias Röhring Assunção. 0 autor registrou memórias transmitidas a trabalhadores rurais por seus antepassados sobre 0 movimento, ao mesmo tempo em que pesquisou as origens do campesinato maranhense: ${ }^{17}$

Este campesinato é formado a partir de três matrizes: indígenas destribalizados, descendentes forros e aquilombados de escravos africanos e finalmente migrantes nordestinos, sobretudo do Ceará. [...] Por outro lado, esta origem pode contribuir para 0 entendimento das variantes do campesinato maranhense: a situação muito diversificada quanto ao acesso à terra (agregado, posseiro, proprietário, etc), a preservação de traços culturais próprios a um subgrupo (por ex. as comunidades negras) ou as 
diferenciações regionais [...]. O campesinato é o suporte principal da Balaiada no M aranhão. [...]. A derrota dos Bem-tevis é devida principalmente a sua desunião quando da promulgação da lei da anistia, a sua falta de posicionamento claro a respeito da escravidão e à maneira pela qual desenvolvem a guerra. Parece-nos que o caráter camponês da maioria dos insurretos bem-te-vis explica o seu sucesso na resistência (dentro da mata) e seu fracasso na ofensiva (a sua dispersão), próprias das guerras camponesas, que raramente conseguem ser vitoriosas. ${ }^{18}$

Contra explicações reducionistas que tornaram a Balaiada um fato histórico homogêneo e linear, o trabalho de Sandra Regina Rodrigues dos Santos, ${ }^{19}$ dez anos posterior aos anteriores, enfatizou a pluralidade de condições socioculturais e objetivos dos rebeldes, insistindo também nas inúmeras contradições existentes no interior do movimento:

[...] procuramos evidenciar que uma complexa teia de contradições permeou a dinâmica do movimento. Leis como a dos Prefeitos e Subprefeitos e a do Recrutamento deveriam ter sido institucionalizadas para sanar situações de abusos e injustiças; ao contrário, sua aplicabilidade constituiu-se numa espécie de rede de aço geradora de grandes injustiças e descontentamentos. Ante a estas leis, práticas sociais comuns no contexto sertanejo foram intensificadas, como, por exemplo, "fazer justiça com as próprias mãos" [...]. As contradições da Balaiada tornaram-se mais nítidas a partir de alguns aspectos, como por exemplo, o relacionamento entre os rebeldes balaios e os liberais bem-te-vis, que não era isento de incompatibilidades e tensões 0 próprio João Lisboa, principal líder liberal, desde 0 início da revolta procurou deixar claro quanto era incompatível o envolvimento dos liberais com os rebeldes. Entretanto, não há dúvidas de que houve uma certa aproximação dos rebeldes com pessoas influentes no contexto sertanejo, em especial os bem-tevis, alguns chegaram a participar efetivamente do movimento. Este aspecto, não se constitui regra geral mas exceção.

[...] Esse, portanto, foi um movimento de revolta de caráter popular, e dada a heterogeneidade de seus componentes, é natural que tenha sido marcado pela pluralidade de características contraditórias e diversificadas, cujos matizes são 
definidores de sua natureza sertaneja. A Balaiada representou a confluência de fatores sociais (desrespeito, opressão, exploração e miséria) e de reivindicações políticas de caráter variado, político-institucional, ou nativistas (suspensão da Lei dos Prefeitos e Subprefeitos, expulsão do presidente da província, expulsão dos portugueses) por uma parcela significativa da população do sertão maranhense, composta de vaqueiros, escravos fugitivos, pequenos artesãos, assaltantes de estrada, agricultores, sem-terra, desertores da Guarda-Nacional, políticos, pequenos comerciantes, fazendeiros, etc. Toda essa complexidade talvez justifique a atualidade do tema [... ${ }^{20}$

Após ter feito minuciosa pesquisa documental sobre os eventos iniciais da rebelião, a autora observa:

Embora não se pretenda neste estudo mudar o eixo oficial da Balaiada, é preciso esclarecer que atos como esses de arrombar cadeias e soltar presos eram comuns no sertão maranhense e neste sentido trato mais adiante de um episódio semelhante do de Raimundo Gomes só que foi cometido por Francisco Ferreira, o Balaio, na cidade do Brejo, no dia 12 de dezembro de 1838, portanto um dia antes do episódio da M anga.

Apesar dessa observação referir-se a um detalhe informativo, levanta dúvidas sobre eventos até então repetidos e aceitos como verdadeiros, sem que se houvesse questionado as afirmações da documentação oficial.

Várias outras versões tidas como inquestionáveis, talvez não resistissem a uma leitura crítica, como por exemplo a origem do nome Balaiada, pelo qual a historiografia consagrou 0 movimento, estar ligada ao fato de Manuel Francisco dos Anjos tecer e vender balaios, atividade modestíssima. Suspeitas podem ser levantadas por ser ter sido ele pequeno proprietário, possuir gado, ter habilidades de exímio cavaleiro, ter libertado presos políticos elíder respeitado do maior bando armado rebelde. ${ }^{22}$ 


\section{DEPOIMENTOS ORAIS}

Atualmente, três historiadoras, - Cecília Helena Salles Oliveira ${ }^{23}$ I sabel M arson, ${ }^{24} \mathrm{M}$ aria de Lourdes Vianna Lyra ${ }^{25}$ - vêm se destacando nos estudos de história política do período monárquico e foram entrevistadas a respeito de questões levantadas pela historiografia da Balaiada.

Primeira questão: Comente a seguinte afirmativa: Existe uma explicação generalista muito difundida sobre os movimentos político-sociais da época da Regência que os considera fruto da crise de autoridade do governo.

Cecília Helena Salles Oliveira - Os políticos que fizeram a separação de Portugal optaram por uma monarquia constitucional e tinham idealizado um perfil de imperador. Como D.Pedro I não cumpriu esse perfil, passaram a questionar de vários lugares sociais, a partir de interesses diversos: - Que perfil de Estado se quer? Que autoridade? Os movimentos são fruto desse questionamento e colocam, isso sim, a autoridade do governo central em crise. Isso fica muito evidente na Regência de Feijó e Araújo Lima. Também penso que não há um grupo econômico hegemônico. Há uma luta pela hegemonia, tanto econômica como política. Há um segmento da sociedade que vai dizer não à política econômica do governo e deseja impor suas diretrizes.

Isabel M arson - Essas interpretações consideram esse período de nove anos da Regência como um período de anarquia política, de desordem, um período que é um interregno lamentável, uma interrupção desnecessária no percurso do Império. E que leitura é essa? Ela está diretamente relacionada com a idéia de que a Regência foi uma primeira experiência republicana no Brasil, experiência que falhou como deveria falhar, porque a tradição do país não era republicana. Há uma idéia de desgoverno, há uma idéia de falência, de agressão à Constituição de 1824, que é entendida como uma constituição moderna, perfeita. Portanto, sob esse olhar, esse período seria sinônimo de desgoverno. Vamos encontrar essa tese principalmente em Justiniano José da Rocha, e mais tarde em Joaquim Nabuco. 
Acho que é possível fazer uma outra leitura dessa "anarquia". 0 que é a anarquia para eles? É a existência de várias instâncias de poder e, sobretudo, é a abertura da possibilidade de participação política, e uma participação política bastante expressiva de uma camada de homens livres pequenos proprietários, mas não apenas na política local, pois essa já existia, por exemplo, na escolha do juiz de paz, uma autoridade significativa, e na constituição da guarda nacional.

Depois, aconteceram alterações e essa participação foi ficando extremamente controlada. I sso que se chama de anarquia, na verdade é uma proposta de desempenho político de setores da população que não tinham voz no período colonial e que foram fundamentais para o sucesso da Independência. Sem o apoio desses médios e pequenos proprietários seria muito difícil preservar a Independência e construir o País. É uma camada de cidadãos que, exatamente pelo fato da experiência da Regência ter sido superada com uma série de reformas políticas posteriores, ficou completamente obscurecida pela formação de dois partidos muito formais, o Liberal e o Conservador.

Maria de Lourdes Vianna Lyra - Realmente existe um esquema explicativo generalista e bastante simplista sobre a época das Regências (1831-1840), que analisa a exaltação dos movimentos sociais - caracterizado por desordens e violências - , como decorrência da crise de autoridade do governo central. Essa é a versão construída nos discursos dos grupos dominantes da época, como forma de justificar a necessidade de centralização do poder para assegurar a unidade do Império, e que passou à historiografia permanecendo ainda hoje em muitos livros didáticos.

No entanto, uma análise mais aprofundada e consistente sobre as conturbações desse tempo histórico - um dos mais dinâmicos em termos de práticas políticas e sociais e um dos menos conhecidos ainda hoje -, nos leva a compreender melhor a singularidade da Independência do Brasil e do processo de estruturação de um Estado nacional unitário em que a monarquia foi mantida como forma centralizadora de governo, bem como a economia baseada no trabalho escravo. Uma reflexão inovadora centrada nestas questões ampliará o conhecimento das estratégias políticas então utilizadas para 
instituir a centralização do mecanismo de poder, no Brasil imperial.

Segunda questão: A memória histórica dos movimentos político-sociais foi construída a partir da ótica do vencedor, o Estado monárquico, e por essa razão atribuiu à maioridade a pacificação do País. Comente essa afirmativa.

Cecília H elena Salles Oliveira - Sob o ponto de vista da historia política, a constituição do Estado monárquico foi por muitos historiadores datada em 1850. No entanto, se tivéssemos que marcar uma cronologia creio eu optaria pelo período de 1853 a 1856. 0 panorama político partidário se altera muito nesse período com a proposta de Conciliação do marquês do Paraná, e a partir daí se constrói uma memória histórica do passado. Concordo que a memória realmente foi forjada, mas ela é forjada depois da Conciliação e não na Maioridade. Essa memória foi construída pluralmente e encontra-se nos escritos de Justiniano, Nabuco de Araújo e outros tantos políticos como Pimenta Bueno, Paulino Souza - visconde de U ruguai.

É uma memória que aniquila a importância desses movimentos que a meu ver foram essenciais, fundamentais, na configuração desses grupos dirigentes que vão conseguir estruturar 0 Estado monárquico em todos os sentidos: presença do Estado em vários pontos do território; elaboração da legislação; estruturação da carreira do exército, da marinha, da magistratura. Essas questões se definem na década de 50 e na década de 60.

Não concordo com a idéia de se atribuir à Maioridade a pacificação do País, porque a M aioridade foi um golpe, um golpe no interior de um movimento mais amplo de questionamento de definição dos próprios grupos que iam dirigir a política nacional no governo central e nas províncias. Esse é um movimento simultâneo e complexo, por essa razão difícil de ser compreendido. Não é possível definir os grupos dirigentes no governo central sem levar em conta essa definição também nas províncias. Não vejo o governo central como sendo impositivo. O governo central tem uma política afirmativa na medida em que ele tem nas esferas locais seus pontos de apoio às suas bases e essas bases se expressam na Câmara dos Deputados e no Senado. 
Isabel Marson - A memória da Regência como anarquia nasceu nos relatos do Partido Conservador, que a partir de 1843 teve longos períodos de hegemonia na administração do Império. M esmo naqueles períodos que chamamos de qüinqüênios liberais ou períodos liberais, o que se tem efetivamente no governo é um grupo de políticos conciliados, do qual os liberais mais exaltados foram expulsos. Isso vai acontecer tanto de 44 a 48, conforme mostra muito bem o historiador Paulo Pereira de Castro, e depois entre 1860 e 68 quando vai se formar a chamada liga progressista.

Se prestarmos bem atenção, a maior parte dos políticos que atuaram neste último período procede do Partido Conservador, começando por Zacarias de Góes, passando por Nabuco de Araújo...O marquês de Olinda, por exemplo, comandou vários ministérios. Por sua vez, Honório Hermeto Carneiro Leão atuou de maneira importante entre 44 e 48. Portanto, temos políticos expressivos que ou eram moderados ou procediam do Partido Conservador. As fontes que constroem essa memória da anarquia principiam em Justiniano José da Rocha na década de 50 e no Instituto Histórico-Geográfico Brasileiro. A revista do IHGB divulgou textos sobre essas revoltas, inclusive a Balaiada, nos quais se acentuou esse caráter de movimento de camadas ou massas ignorantes, barbárie, etc. Depois quem selou e divulgou essa imagem foi o texto do Estadista do Império de Joaquim Nabuco: - ele assumiu a interpretação que Justiniano construiu para o período regencial e para todas as revoltas, inclusive a Praieira, historiada com maior cuidado. Nabuco a interpreta como um "turbilhão popular" desenfreado no sentido negativo da expressão.

Outro livro também importante na construção dessa memória é "M emórias do meu tempo," de Pereira da Silva, que é um político genuinamente conservador. Joaquim Nabuco embora oficialmente um liberal, poderia ser considerado um liberal de cepa conservadora. Já Justiniano José da Rocha foi sempre um ferrenho conservador, opção claramente colocada no texto Ação, Reação e Transação. Poderemos encontrar nuances e uma polêmica sobre esta leitura da "anarquia", por exemplo, em Teófilo Otoni, na sua Carta aos Eleitores, de 1860. Trata-se de um depoimento muito importante, que faz uma rememoração e outra leitura da Regência, muito próxima dessa que comentei.

Maria de Lourdes Vianna Lyra - O tempo das Regências caracterizou-se como um dos mais dinâmicos em termos de luta 
entre grupos sociais de condições e interesses diversos, em prol da definição das estruturas do Estado imperial. Esse foi o tempo da explosão do ideal de liberdade do homem, um tempo marcado sobretudo pela exacerbação das atitudes dos grupos liberais mais "exaltados", ou seja, de predomínio da ação daqueles que reagiram com maior intensidade ao peso da centralização do poder político instituído pela Constituição do Império, e que defenderam com fervor a ampliação do direito de participação política na sociedade que se estruturava.

É importante lembrar que os liberais "exaltados" lutavam não apenas contra a acumulação de atribuições de poder no Executivo, mas também contra a administração centralizadora do Estado imperial - que atrelava as províncias ao governo geral -, e contra a política que centralizava na Corte do Rio de Janeiro o montante da arrecadação proveniente do pagamento dos impostos sobre a comercialização da produção local. Essa era uma luta travada desde os primeiros anos da Independência pelos liberais "radicais", que pleiteavam a distribuição eqüitativa dos poderes constitucionais e a autonomia das unidades administrativas (as províncias), defendendo que fosse concedida a elas a prerrogativa da escolha de seus próprios governantes (os presidentes de província), além da institucionalização de assembléias legislativas próprias para criar suas leis específicas, e da retenção das rendas locais, sumamente necessárias ao desenvolvimento de cada província.

É nesse contexto que devem ser analisados os conflitos de interesses e as turbulências então ocorridas entre o poder constituído e instalado no Rio de Janeiro e os agentes defensores da autonomia política e fiscal, bem como a mobilização dos grupos dirigentes em torno da maioridade do imperador menino, como "instrumento providencial" de restauração da ordem e de salvaguarda da unidade do Império, que al egavam estar ameaçada.

Terceira questão: Tendo em vista sua experiência de pesquisa, considera que há traços comuns entre a Balaiada e outro(s) movimento(s) da época?

Cecília H elena Salles Oliveira - Eu penso que há traços comuns, sim, entre a Balaiada e outros movimentos da época, a despeito da especificidade do M aranhão e da Região Norte; é uma especificidade que aparece muito claramente já no momento da Independência. Todo processo da separação de Portugal, as negociações do governo 
do Rio de Janeiro para com as lideranças e os grupos políticos e sociais do Maranhão foram pautadas em ações diversas das que ocorriam em relação a M inas Gerais, a São Paulo, ao Rio Grande do Sul, foram de muita violência, é verdade, porque realmente houve confrontos armados naquele momento.

A despeito dessas especificidades, nas décadas de 1820 e 1830 há um ponto comum que é a percepção por parte de determinados segmentos da sociedade da época do Império - sitiantes, pequenos produtores, soldados, libertos - de que era o momento de exigir uma maior participação popular na definição das autoridades, como por exemplo na eleição dos juízes de paz, na eleição dos que iam governar as cidades e nas eleições parlamentares. Tinham a perspectiva de efetivamente tornarem concretas algumas reivindicações que vinham até da época das cortes de Lisboa, que estavam na base da Constituição de 1822 de Portugal e que não foram adotadas aqui.

$\mathrm{Na}$ época do Império, acontece no Brasil uma situação muito curiosa e dramática. 0 movimento constitucional em Lisboa e no Porto abriu aqui um campo de debate muito grande pela imprensa da época da separação de Portugal. Havia uma participação no sentido dos jornais serem lidos em praça publica, de haver uma mobilização popular, e eu acho que essa mobilização popular caminhava na direção do estabelecimento de um governo constitucional nos moldes possíveis na primeira metade do século XIX, como aconteceu na Inglaterra, nos Estados Unidos, como aconteceu na França também.

A documentação posterior de 1850 demonstra que ao invés de haver uma ampliação da base de participação popular, o que ocorre é que em direção ao final do Império há um fechamento dessa participação. 0 voto ficou cada vez mais preso aos princípios censitários.

Essas movimentações da primeira metade do século XIX acabaram sendo canalizadas para um fechamento e não para uma concretização dessas reivindicações iniciais que se percebe principal mente através da imprensa.

Estudar esses movimentos sociais é também reconstituir, compreender possibilidades históricas que existiram, mas que não puderam efetivamente se concretizar, e aí fica a pergunta: - por que não se concretizaram? Por que rei vindicações como extinguir o Poder Moderador e descentralizar as decisões dos ministérios, feitas no momento mesmo que a Carta Constitucional de 1824 foi imposta, não se concretizassem? 
0 que fez com que muitos políticos que reivindicaram essas mudanças, quando chegaram ao poder, não as implementaram? 0 que havia nessa estrutura política fora da Carta de 24 que fazia com que mesmo as oposições quando chegavam ao poder desistissem de alterá-la? Deixavam-se fascinar por essa estrutura de poder que eles desdiziam? A Carta Constitucional de 1824 não era considerada ilegítima por muitos. $\mathrm{O}$ que que aconteceu? Aqueles mesmos que as consideraram ilegítima, a legitimaram durante a Regência. $O$ Ato Adicional legitimou a Carta e a transformou em Constituição. Os liberais posteriores, a outra geração de políticos liberais, legitimou-a ainda mais. Por isso que na memória ficou como Constituição de 24, só que ela foi legitimada depois por aqueles mesmos que a tinham condenado.

Isso é um enigma talvez intuído por Tito Franco ao escrever, no início de seu livro sobre o consel heiro Furtado, que na história do Império há uma esfinge que devora os seus filhos, essa metáfora devemos trabalhar mais profundamente.

Talvez medos de uma revolução dos libertos, dos posseiros ou dos sitiantes, dessas pessoas, talvez?

Aquelas reivindicações de muitos segmentos da sociedade na época da separação de Portugal foram levadas até meados da década de 30, mas depois acabaram se perdendo. 0 que selou essa perda de espaço desses segmentos foi a própria lei do Parlamento, a lei eleitoral de 1846, que estabeleceu que o censo deveria ser medido pela moeda de prata e não mais pela de cobre. A moeda de cobre fazia com que praticamente houvesse um voto universal, porque cem mil réis não valiam nada. A moeda de prata estabelecia realmente uma nova hierarquia de voto censitário.

Há mais semel hanças entre os cabanos, a Balaiada, a Sabinada, alguns movimentos que ainda não foram suficientemente estudados em M inas Gerais, em São Paulo, talvez no Rio de Janeiro.

Temos movimentos interessantes na região de Franca, na região do vale do Paraíba que antecedem a Revolução de 42, que mereceriam um olhar mais específico. É como se depois da década de 40 e da conciliação esses segmentos não fossem mais ouvidos. Talvez porque a sociedade tenha mudado muito nesse período.

A Revolução Farroupilha é diferente, não porque os segmentos sociais que nela atuaram tenham sido diferentes, porque a questão ali era uma questão muito imbricada com interesses ramificados na antiga Cisplatina que não tinham sido resolvidos nem com a separação nem com a guerra. Porque muitos dos estancieiros e dos 
fazendeiros que lutaram na Farroupilha de um lado e de outro tinham gado na antiga Cisplatina tinham interesses ali, negociavam com ingleses e com outros estrangeiros que queriam a navegação livre naquela região, no Prata, e tinham muitas ramificações também envolvendo os governos que se estabeleceram no U ruguai, por isso que eu acho que ela é diferente porque eram os antigos castelhanos, os antigos portugueses radicados ali. Os interesses foram se desdobrando até na Guerra do Paraguai, e de novo os conflitos se tornaram muito evidentes.

Ao lado desses problemas relacionados aos governos do Uruguai e da Argentina colocavam-se as questões do tráfico de escravos. Algumas pesquisas demonstraram que houve uma ligação muito grande entre políticos de São Paulo com os do Rio Grande nesse período da Revolução Farroupilha. Tudo indica que uma das formas de ligação está justamente no tráfico de escravos.

Isabel Marson - Há aproximações e também singularidades. $N$ as aproximações poderemos localizar algumas questões políticas de fundo. Existe em todos esses movimentos um desejo de pacto político afinado com interesses locais, porque essas províncias brasileiras têm singularidades sociais e singularidades econômicas e um anseio generalizado de que as individualidades sejam respeitadas. Outro traço que aproxima é o desejo de que se possibilite voz política mais expressiva para esses setores da sociedade compostos pelos eleitores, um pouco menos pelos votantes, e se reforme o sistema censitário. Esses pequenos proprietários querem um pacto político que permita ter suas reivindicações mais respeitadas e atendidas.

Existem também algumas mudanças estruturais e econômicas que atingem todas as províncias e que também estão na origem dos movimentos. Existe uma expansão agrícola e comercial em todas as grandes províncias nesse período, pelo fato de que a Independência liberou um número muito grande de atividades que estavam sob monopólios, franqueou mais acesso às terras que antes eram terras da Coroa, permitiu que houvesse uma agilização econômica e novas camadas proprietárias e elas querem um espaço político. Então essa alteração no mundo dos negócios gera uma sociedade mais ágil, que quer enfim uma participação política.

Essas mudanças que vêm em função de questões históricas mais profundas, que atingiram todas as províncias, podem estar na origem tanto dos movimentos de 31 que depuseram D.Pedro, quanto 
na Sabinada, na Balaiada, na Praieira, um período de lutas por um pacto político que permitisse uma participação de mais camadas.

Vamos às especificidades: vou falar mais da Praieira, que conheço, e a Balaiada, que no caso é o movimento em questão. As atividades econômicas desenvolvidas em Pernambuco e no $M$ aranhão têm configurações diversas. Em Pernambuco temos uma área grande de engenhos, de grandes, médios e pequenos engenhos, na Zona da M ata e no Agreste, área muito importante política e economicamente. Essa conformação, esse domínio do açúcar na economia pernambucana vai fazer com que a sociedade também tenha um perfil bem peculiar se comparável com o do Maranhão. Nem de perto há nessa área hegemônica de Pernambuco a predominância daquela camada de vaqueiros, índios e caboclos e escravos fugidos. O controle em Pernambuco é muito maior, havia uma escravaria maior do que no $M$ aranhão, por conta dos engenhos, mas uma escravaria que está numa área de um controle muito grande.

Não vou encontrar escravos atuando em postos de comando na Praieira. Há proprietários de diferentes atividades se enfrentando numa guerra civil, na qual em nenhum momento significativo perderam o controle da condução da guerra. A pergunta que se poderia fazer seria então: - não há sucedâneo dos balaios em Pernambuco? Sim, há quilombos e índios aldeados nas matas de Alagoas, muitos deles ligados aos grandes proprietários da região e ao bando de Vicente Ferreira de Paula, mas seu desempenho não teve autonomia semelhante àquela dos balaios na Balaiada. Na Praieira eles lutaram junto com senhores-de-engenho, junto com moradores, foram importantes no ataque a Recife, mas retiraram-se da cidade juntamente com seus chefes.

Um grupo que poderia eventualmente se parecer com os balaios seria o dos "cinco mil", que são votantes das eleições primárias, oriundos do pequeno comércio e artesanato do Recife, trabalhadores do porto, mas que tiveram uma participação muito discreta na guerra civil propriamente dita. Foram muito importantes nas eleições que elegeram os praieiros e em manifestações urbanas que precederam a guerra civil, mas como aliados políticos já estavam marginalizados desde o início de sua aproximação com a Praia. Por isso, seus movimentos do gênero "mata-marinheiro" aconteceram no Recife em junho de 1848, antes da Revolta Prai eira. Quando a revolta da Praia teve início eles já estavam rompidos com os praieiros. 
Uma proximidade muito interessante entre a Balaiada e a Praieira, é que a ascensão de Araújo Lima ao poder, assinalando uma guinada conservadora, marca o início dos dois movimentos: - a Balaiada surge em sua ascensão em 37 como regente, e a Praieira estoura depois de sua ascensão ao ministério em 1848, substituindo o gabinete liberal de Paula Sousa. Essa constatação se relaciona à política de fundo que destaquei. A ascensão conservadora foi efetivamente uma ameaça para esses setores que queriam espaço político.

Maria de Lourdes Vianna Lyra - A rejeição à política centralizadora do Estado imperial é o traço comum existente entre os movimentos de reação provincial que eclodiram no Brasil no tempo das Regências. Para maior clareza dessa questão é preciso ampliar o quadro de análise e centrar a atenção na empreitada política de construção e consolidação das estruturas do I mpério do Brasil.

A eficiência da administração dependia do orçamento equilibrado entre receita e despesa. $M$ as a instabilidade política que vinha perdurando desde a Independência, as dificuldades de crescimento da renda pública e os gastos excessivos com 0 empreendimento da construção do Império eram fatores que emperravam a administração do Estado brasileiro. Um dos maiores entraves para a adesão das províncias aos planos do governo central era a obrigatoriedade da contribuição financeira para as despesas gerais do I mpério. U ma parcela considerável dos médios e pequenos proprietários rurais não aceitava as propostas de direcionar parte das rendas locais em benefício da região-sede da Corte imperial, assim como se opunha à perda da representatividade autônoma dos municípios. Os grupos urbanos também se opunham a essas medidas, pois entendiam que a união imperial deveria se dar em outras bases.

$\mathrm{Na}$ discussão em torno da reforma constitucional, os grupos dirigentes defenderam a proposta de centralização das rendas de todas as províncias no governo central, que distribuiria os recursos de acordo com as maiores ou menores necessidades de cada uma delas. Com a classificação das fontes de receita geradora das rendas públicas, a partir de 1832, o governo fazia com que todas as províncias contribuíssem com os gastos do Império - velha aspiração só então realizada -, livrando-se do desgaste dos apelos quase nunca atendidos para 0 envio dos saldos provinciais e ainda invertia 0 sentido da dependência financeira entre centro e províncias. Assim, o 
governo retirava das províncias mais ricas - sobretudo Bahia, Pernambuco e Maranhão -, o montante dos rendimentos nelas gerados pela exportação de açúcar, algodão, fumo e cacau, produtos de maior peso na balança comercial até então.

A nova política de arrecadação das rendas aumentava substancialmente a receita geral, que alcançava um montante quase três vezes maior do que o teto máximo do rendimento referente à receita provincial. E representava um corte aproximado de mais da metade do que era arrecadado, e até então retido nas províncias. Estabelecia-se, a partir de então, uma prática que retirava os recursos próprios de cada província para depois socorrêlas em caso de necessidade, forma perfeita para fortalecer a tutela do Estado e barrar os movimentos rei vindicatórios de autonomia provincial.

O caráter de "movimentos separatistas" atribuído pelo governo geral às revoltas provinciais ocorridas, a partir de então, é um tema que ainda exige pesquisa mais cuidadosa e reflexão mais aprofundada. Apesar da radicalização de tais movimentos, que chegaram a instalar governos republicanos, foi comum na maioria deles a declaração do sentimento de unidade com o Brasil, ao mesmo tempo em que manifestaram com determinação o repúdio à retirada da autonomia local, que implicava sobretudo a imposição dos governos provinciais e o esvaziamento das próprias rendas. Por essas aparentes contradições percebe-se quanto essa temática ainda exige reflexão, não apenas para maior compreensão do processo político de construção, do Brasil como também para maior clareza sobre a formação histórica de identidade brasileira.

As três interpretações apresentam várias semelhanças entre si, bem como com a minha maneira de compreender a Balaiada, representando uma mesma raiz teórica na qual se entrelaçam as várias instancias da política, da economia e da vida social, em consonância com a metodologia preconizada pelos historiadores franceses dos Analles, que sempre estiveram presentes na produção histórica acadêmica.

\section{RESSIGNIFICAÇÃO DA MEMÓRIA}

Com o passar do tempo a memória da Balaiada assumiu novos significados bem distintos daqueles próprios de seu contexto histórico. Uma rápida consulta às informações 
veiculadas na Internet indica uma variada gama de instituições ou pessoas que usam a Balaiada, de forma muitas vezes contraditória, para justificar posições ideológicas. Alguns exemplos são ilustrativos do processo de resignificação da memória balaia. ${ }^{26}$

Demonstrando atitude extremamente conservadora, o Índice História M ilitar do Brasil ${ }^{27}$ transcreve trecho do livro 0 Exército na História do Brasil.:28

A Balaiada foi um movimento subversivo irrompido em uma pequena vila maranhense que se alastrou por toda Província e ameaçou as regiões vizinhas. Recebeu o nome de Balaiada em referência a um de seus líderes, um fabricante de balaios $M$ anuel Francisco dos Anjos Ferreira, apelidado Balaio. Era um típico representante do N ordeste, homem resistente, de tez morena e cabeça achatada.

Se a separação maranhense tivesse se consumado, causaria grande transtorno em nossa configuração territorial, afetando a integridade nacional (p.1).

Raimundo Gomes tornou-se um perigo para a ordem pública, já que era chefe de uma revolta sem ideal, sem bandeira, e sem outros objetivos senão 0 saque e a obtenção de vantagens pessoais. "O colorido político era aí mero pretexto para demonstrações do mais desenfreado banditismo sertanejo", escreveu Hélio Vianna. (p.2).

Em sentido diametralmente oposto o movimento para a Erradicação do Trabalho Escravo no Maranhão, em sua publicação n.6 divulga o seguinte texto:

Balaiada: resistência popular no M aranhão.

"O Balaio chegou! O Balaio chegou.

Cadê branco? Não há mais branco!

Não há mais sinhô."

(Cantiga dos Balaios)

N O M ARANHÃO, QUASE 170 ANOS ATRÁS... OS ESCRAVOS TAM BÉM SE ORGANIZARAM CONTRA A ESCRAVIDÃO. FIZERAM UMA GRANDE REVOLTA CONHECIDA COMO A BALAIADA. 
M aranhão: Triste troféu de exportador de escravos.

O Estado do M aranhão ganha o troféu de uma triste disputa:

É o campeão de exportação de mão de obra escrava.

N ossos trabal hadores maranhenses são levados como escravos

para todo o Brasil, principalmente para o sul do Pará.

O segundo Estado que mais exporta escravos é o nosso vizinho

Piauí.

Aqui, como lá, é a mesma pobreza, fome e miséria.

Quase $40 \%$

de todo o trabalho escravo utilizado

no Brasil vem do M aranhão.

Também é possível identificar-se a reinvenção da tradição balaia em sitios políticos, religiosos e institucionais:

Sitios de alguns deputados federais e estaduais do M aranhão e Piauí: a Balaiada é mencionada em discursos ou no panorama histórico do estado a que pertence o político responsável pelo sítio, significando luta popular, luta contra a opressão, luta contra a ditadura.

Sitio de Edgar Rodrigues sobre o movimento anarquista: a Balaiada é reconhecida como uma revolta exemplar de cunho anarquista.

Sitio do PCB: a Balaiada é incluída na tradição dos movimentos revolucionários populares.

Sitio de movimentos pentecostais: a Balaiada como integrante da tradição religiosa da população pobre do Brasil.

Sitio da Pastoral da Terra: A luta dos sem-terra desde a época da Balaiada.

Sitio do Partido dos Trabalhadores, Diretório Nacional. Entrevista de Pedro Girolimish, vice- presidente da UBES (União Brasileira dos Estudantes), datada de 12 de julho de 2004, falando sobre o Projeto N ova Escola:

A luta pela educação pública e de qualidade sempre esteve associada aos movimentos populares e setores progressistas da sociedade. Um grande referencial na luta da UBES pelo Projeto Nova Escola é Negro Cosme, que dedicou boa parte de sua militância a organizar a revolta da Balaiada, através da primeira 
escola de caráter popular e democrática, sendo o último líder a ser morto pelas tropas imperiais.

Sitio do Centro de Cultura Negra do Maranhão (CCN M A): divulga o texto em literatura de cordel de Magno José Cruz:

A epopéia dos guerreiros balaios na versão dos oprimidos

Foi em mil e oitocentos / No ano de trinta e oito / Quando explodiu a Balaiada / Com muitos cabras afoitos / Pra agarrar a burguesada / E (ó) cortar-Ihe o pescoço.

Brigavam "bentevis" e "cabanos" / Na política do Maranhão / Briga de jornal (lero-lero) / Vejam a comparação: / Briga de Sarney e Castelo / Pra enganar Zé Povão.

A Província naquela época / Tinha problemas sociais / Sofriam caboclos e negros / Com os preconceitos raciais / Fome, "pega", desemprego / Tudo consta nos anais.

Esses negros organizados / Chamados de quilombolas / Viram na Balaiada / Que era chegada a hora / Da liberdade sonhada /

Renascer naquela aurora.

Cosme Bento das Chagas / Logo então se destacou / E lá de Lagoa Amarela / Três mil negros libertou / E com tal valentia cega / A Balaiada engrossou.

Ali Negro Cosme implantou / Uma conceituada escola / Para ensinar ler e escrever / À toda massa quilombola / Q ueria o líder dizer: / "Façamos nossa história."

$\mathrm{N}$ a história que tem nos livros / Escritos pela burguesia / Cosme é o grande bandido /

(Ora vejam, quem diria!) / E Luís, racista assumido / É o herói duque de Caxias.

Da mesma forma, a "Cartilha Projeto Vida de Negro. 10 Anos de Luta pela Regularização e Titulação das Terras de Preto no Maranhão", refere-se à Balaiada e aos quilombolas com citações de historiadores contemporâneos e cronistas da época, ${ }^{29}$ inventando uma tradição de luta pela terra que remonta aos batal hões negros da época da regência.

A cultura carnavalesca explorou com sucesso tradições maranhenses com o samba-enredo da Escola Grande Rio (2002), de autoria de Alailson Cruz e Agenor N eto, e que contou com 0 
carnavalesco Joãozinho Trinta: Os papagaios amarelos nas Terras encantadas do M aranhão. ${ }^{30}$

... De além-mar quem vem (hê, hê),

Portugal, meu bem,

Expulsando o francês e o bravo holandês.

Também

No balaio tem a revolução, a Balaiada!

Negro Cosme quer seu povo feliz,

0 imperador das liberdades bem-te-vis,

Meleva que eu quero ver (eu quero ver)

Touro negro coroado,

Ele é dom Sebastião,

Que no mar fez o seu reino

Num palácio iluminado.

Hêpovo, hê povo, hê

HêM aranhão, povo encantado...

\section{CONSIDERAÇÕES FINAIS}

Eis, de forma concisa, como veio sendo construída a memória e a história da Balaiada. Há, contudo, um substrato narrativo que tem permanecido em todas as linhas interpretativas e versões, garantindo a configuração do saber histórico.

À primeira vista, a leitura do conjunto da produção atual da historiografia brasileira induz a pensar na fragmentação do discurso histórico e na recusa da idéia de totalidade. Porém, em seu conjunto, as obras referem-se, em todos os momentos da História do Brasil, a projetos ferozes visando à dominação que, partindo do Estado, das classes ou das elites, têm por objetivo perseguir, excluir, enganar. Esse grande enunciado mergulha toda essa produção na instância do político, solidarizando-a com a matriz principal do nosso pensamento historiográfico, reconciliando-se com a tradição dos nossos bons historiadores.

Em uma perspectiva abrangente, nas obras historiográficas - Brasil não é ainda concebido como uma nação, e sim como um território em formação, com espaços de exclusão, onde se exerce a mais feroz dominação econômica e social. Os atuais historiadores a descobrem nas representações discursivas ou em 
outras linguagens. Não pode ser diferente, a consciência da exclusão que brota da realidade brasileira é por demais poderosa e imperativa, e é por isso que a nossa historiografia tem nela a sua maior referência.

JANOTTI, Maria de Lourdes Mônaco; Balaiada: construction of an historical memory. História, Franca, v.24, n.1, p.41-76, 2005.

ABSTRACT: During the 19th century, historians tried to explain how the Brazilian national State was born, attributing to the institutions of the new country a constitucional renovator and civilized character. In this measure, the contesters' movements, between them the Balaiada, were judge as anomalies, barbarity manifestations against the civilization, represented by the monarchist order. However, memorialistics sources propagated different versions of the Balaiada revolt, rich in details and nuances, allowing the apprehension of mannering of emergent social segments of the crisis in the end of the colonial period. Entering in the 20th century historians had understood that the Balaiada represented the ascension of Brazilian people to the provincial and national power, the consolidation of the private power and the domination pact between the parties of the maranhense elite, accenting even more the social marginalization of the dismissed, especially the negros.

KEYWORDS: Balaiada; maranhenses parties; Regency revolts.

\section{NOTAS}

\footnotetext{
1 Departamento de História - Faculdade de Filosofia, Letras e Ciências Humanas - USP. CEP 05508-900.e-mail: mljanott@usp.br

2 JANOTTI, Maria de Lourdes Monaco. João Francisco Lisboa: Jornalista e Historiador. São Paulo: Ática, 1977, p.230.

${ }^{3}$ Jornal do Comércio: Rio de Janeiro, 1941.

${ }^{4}$ Idem, p.78 e 79 .

${ }^{5}$ Apelido de Garcia de Abranches.
} 
${ }^{6}$ Moura, J. Dunsheee de Abranches. O captiveiro. Memórias. Rio de Janeiro: Jornal do Comércio, 1941, p.101-102.

${ }^{7}$ Idem, p. 145 .

${ }^{8}$ JANOTTI, Maria de Lourdes Monaco. Três mulheres da elite maranhense. Revista Brasileira de História, ANPUH/Contexto: São Paulo, v.16, n.31/32, p.225-248, 1996.

${ }_{9}^{9}$ CARVAlHO, Carlota. O Sertão. Rio de Janeiro: Empresa Editora de Obras Científicas e Literárias, 1924.

${ }^{10}$ SERRA, Astolfo. A Balaiada. Rio de Janeiro: Bedeschi, 1946.

11 ABRANTES, Elizabeth Sousa. A Balaiada $e$ os balaios: uma análise historiográfica. São Luís, 1996. Monografia ( Trabalho de fim de curso de História) - Universidade Federal do Maranhão.

${ }^{12}$ Idem, p. 15.

${ }^{13}$ Idem, p.21.

${ }^{14}$ A Balaiada e a Insurreição de Escravos no Maranhão. São Paulo, Ática, 1983.

${ }^{15}$ Idem, p.106-107.

${ }^{16}$ JANOTTI, Maria de Lourdes Monaco. A Balaiada. São Paulo: Brasiliense, 1987.

${ }^{17}$ A guerra dos bem-te-vis. A Balaiada na memória oral. São Luís: Sioge, 1988.

${ }^{18}$ Idem, p.217 a 221.

${ }^{19}$ A Balaiada no sertão. A pluralidade de uma revolta. Franca, 1998. Dissertação (mestrado em História) - Unesp/Franca.

${ }^{20}$ Idem. Ver: Considerações finais. Os rebeldes balaios, nem heróis nem bandidos: sertanejos em luta.

${ }^{21}$ Idem.

${ }^{22}$ A palavra balaiada teve e tem muitos significados, tais como: componente de sela de montaria; confusão; dança trazida pelos açorianos; quadris; desordem; festa; derrota por muita desvantagem em relação ao adversário; conjunto de festas e comemorações; muitos cestos ou balaios; coletivo de muitos objetos; discurso feminino - reclamações, contestações, indignação, conversa fiada. É possível que se tenha generalizado o uso de uma dessas várias acepções, algumas usadas desde o século 19, para designar a revolta dos pretos, forma como a população sertaneja se recorda do movimento regencial. De qualquer modo, ainda há muito que esclarecer sobre os acontecimentos da revolta maranhense.

${ }^{23}$ Professora do Departamento de História da USP. Entre os livros e artigos que publicou destacamos por ser mais condizente com a temática das perguntas, A Astúcia Liberal. Bragança Paulista: Universidade São Francisco/Ícone, 1999. Entrevista concedida em São Paulo, 11/ago/2005.

${ }^{24}$ Professora do Departamento de História da UNICAMP. Entre os livros e artigos que publicou destacamos, por ser mais condizente com a temática das 
perguntas, O Império do Progresso. A Revolução Praieira (1842-1855). São Paulo: Brasiliense, 1987. Entrevista concedida em São Paulo, 16/ago/2005.

${ }^{25}$ Membro efetivo do Instituto Histórico Geográfico Brasileiro. Entre os livros e artigos que publicou destacamos A Utopia do Poderoso Império. Portugal e Brasil: Bastidores da Política 1798 - 1822. Rio de Janeiro: Sette Letras, 1994. As respostas foram enviadas por e-mail, 16/ago/2005.

${ }^{26}$ As informações foram colhidas em 1 de setembro de 2005.

${ }^{27}$ Site: cadete.amn.ensino.eb.br/histgo/HistoriaMildoBrasil/Balaiada/balaiada.htm

${ }^{28}$ BiBliEx:Rio de Janeiro/ Odebrecht:Salvador, vol 3, 1998.

29 Integrante do Projeto Vida de Negro. Edição CCN / SMDH (1998). www.ccnma.org.br

${ }^{30}$ www.artes.com/carnaval/escolas $1 . h t m l$

31 D’ALÉSSIO, Márcia Mansor; JANOTTI, Maria de Lourdes Monaco. A esfera do político na produção acadêmica dos programas de Pós-Graduação (1985/1994). Estudos Históricos, Fundação Getúlio Vargas: Rio de Janeiro, v.9, n.17, p.123-149, 1996.

Artigo recebido em 04/2006. Aprovado em 05/2006. 